\title{
HLA antigens and acetylcholine receptor antibody in the subclassification of myasthenia gravis in Hong Kong Chinese
}

\author{
BR HAWKINS, ${ }^{*}$ MSM IP, $\dagger$ KSL LAM, $\dagger$ JTC MA, $\dagger$ WY CHAN-LUI, $\ddagger$ RTT YEUNG $\dagger$ \\ RL DAWKINS§
}

From the Departments of Pathology,* Medicine $\dagger$ and Paediatrics, $\ddagger$ University of Hong Kong, Hong Kong, and the Department of Pathology, University of Western Australia.§

SUMMARY Thirty seven Chinese adults and 23 children in Hong Kong with myasthenia gravis were tested for HLA-A and -B antigens and acetylcholine receptor (AChR) antibody. HLA BW46 had a significantly increased prevalence in patients with juvenile onset ocular myasthenia gravis. Only one third of the juvenile ocular patients had AChR antibodies and the titres were generally low. In the adult patients taken as a whole there was a non-significant increase in the prevalence of HLA B5 and HLA B15. HLA BW46 was more prevalent in adult patients without AChR antibody and less prevalent in patients with AChR antibody but the findings were not statistically significant. It is suggested that ocular myasthenia gravis is determined by a pathological mechanism for whic/ susceptibility is determined by HLA BW46. There was a strong correlation between ocula $\frac{}{5}$ myasthenia gravis and Graves' disease in the adult patients. The possibility that ocular myasthenia gravis is accentuated by a BW46-associated predisposition to ocular Graves' disease is considered

Myasthenia gravis is a heterogeneous disease. Some patients have involvement of the extra-ocular muscles only and are considered to have "ocular myasthenia gravis" whereas others have disease extending beyond the extra-ocular muscles and are classified as having "generalised myasthenia gravis". ${ }^{1}$ The discovery ${ }^{2}$ of antibodies to the acetylcholine receptor (AChR) in the serum of most patients with generalised myasthenia gravis but less frequently in patients with ocular disease led to the question whether generalised myasthenia gravis and ocular myasthenia gravis represent different diseases or whether ocular myasthenia gravis is a less severe form of the generalised disease. ${ }^{3}$ The accumulated evidence appears to favour the suggestion that ocular and generalised myasthenia gravis represent different disorders. ${ }^{4}$ It is now well established, for example, that HLA B8 in Caucasian patients occurs frequently in females with generalised

Address for reprint requests: Dr BR Hawkins, Department of Pathology, University of Hong Kong, Queen Mary Hospital Compound, Hong Kong.

Received 17 May 1985 and in revised form 12 August 1985. Accepted 25 August 1985 myasthenia gravis of early adult onset and particte $\overrightarrow{0}$ larly in those with thymic hyperplasia rather tha thymoma. ${ }^{5}$ In patients with late onset myasthenia gravis there is an increased prevalence of HLA B7, ${ }^{6}$ but there is no convincing evidence for an association of ocular myasthenia gravis with the HLA system in $\overline{0}$ Caucasians. ${ }^{4}$ Previously we have reported a $\frac{0}{8}$

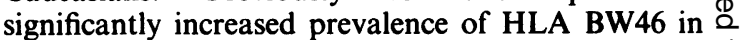
Southern Chinese myasthenic children in Hong Kong, $\overrightarrow{\overrightarrow{0}}$ most of whom had ocular myasthenia gravis. ${ }^{7}$ The 3 purpose of the present study was to compare the HLA antigen profile of Chinese adult myasthenic patients with that of the juvenile patients reported previously ${ }^{7}$ and to examine the distribution of acetylcholine $\frac{7}{0}$ receptor antibody titres in different categories of myasthenia gravis in Hong Kong Chinese.

\section{Materials and methods}

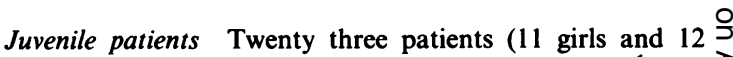
boys) with ocular myasthenia gravis were studied including $\frac{7}{2}$ 21 who were described in the previous report ${ }^{7}$ and two patients not reported previously. Three patients in the pre- $N$ vious study with generalised myasthenia gravis and three others whose AChR antibody status was not available are $N$ 
not included in this report. The patients had been followedup for between one and sixteen years.

Adult patients Thirty seven previously unreported adult patients with disease onset above 13 years of age were studied including 21 with generalised myasthenia gravis, 13 with ocular myasthenia gravis, and three whose clinical type was not recorded. The adult patients had been undergoing treatment or follow-up for a minimum of two years.

All patients, adults and children, were Chinese and most originated from Southern China. As in the previous study ${ }^{7}$ the diagnosis of myasthenia gravis was based on undue muscle fatigability which could be significantly relieved by intravenous edrophonium and maintenance anticholinesterase medication and the exclusion of other neuromuscular disease. Thirteen of the adult patients had accompanying thyrotoxic Graves' disease defined as hyperthyroidism associated with diffuse hyperplasia and hypertrophy of the thyroid gland. ${ }^{8}$ Two of the juvenile patients had thyrotoxicosis but did not satisfy these criteria for Graves' disease.

Controls The control group consisted of 110 Southern
Chinese undergraduate entrants to the University of Hong Kong reported previously ${ }^{79}$ who were having blood taken as part of their routine medical examinations.

HLA typing Peripheral blood lymphocytes from patients and controls were tested for a range of HLA-A and -B antigens by the standard microcytotoxicity test using between 100 and 120 different sera obtained from local donors, through exchange programs, or purchased commercially.

Acetylcholine receptor antibody Antibody was assayed using an immune precipitation method described by Garlepp et $a^{10}$ utilising human AChR labelled with alphabungarotoxin. Anti-AChR titre was expressed in units approximately equivalent to nanomoles of toxin binding sites precipitated per litre of serum.

Results

The HLA phenotypes, clinical details, and AChR antibody titres of the 37 adult patients are shown in table 1. Records were not available on the type of

Table 1 HLA phenotypes, acetylcholine receptor antibody titres and clinical details of 37 adult onset myasthenics

\begin{tabular}{|c|c|c|c|c|c|c|c|}
\hline Number & Sex & $\begin{array}{l}\text { Age at } \\
\text { onset (yr) }\end{array}$ & $H L A-A$ & $H L A-B$ & Anti-AChR & $\begin{array}{l}\text { Clinical } \\
\text { type }\end{array}$ & $\begin{array}{l}\text { Graves' } \\
\text { disease }^{*}\end{array}$ \\
\hline $\begin{array}{l}\text { MG } 817 \\
\text { MG } 799 \\
\text { MG } 488 \\
\text { MG } 964 \\
\text { MG } 786 \\
\text { MG } 491 \\
\text { T } 2612 \\
\text { T } 930 \\
\text { MG } 957 \\
\text { MG } 928 \\
\text { MG } 516 \\
\text { T } 2329 \\
\text { T } 2255 \\
\text { T } 2893 \\
\text { T } 832 \\
\text { T } 563 \\
\text { T } 572 \\
\text { MG } 842 \\
\text { T } 1938 \\
\text { T } 2169 \\
\text { T } 833\end{array}$ & $\begin{array}{l}\mathbf{F} \\
\mathbf{F} \\
\mathbf{F} \\
\mathbf{F} \\
\mathbf{F} \\
\mathbf{F} \\
\mathbf{F} \\
\mathbf{F} \\
\mathbf{F} \\
\mathbf{F} \\
\mathbf{F} \\
\mathbf{F} \\
\mathbf{F} \\
\mathbf{F} \\
\mathbf{F} \\
\mathbf{F} \\
\mathbf{M} \\
\mathbf{F} \\
\mathbf{F} \\
\mathbf{M} \\
\mathbf{M}\end{array}$ & $\begin{array}{l}30 \\
27 \\
26 \\
28 \\
13 \\
27 \\
25 \\
34 \\
30 \\
17 \\
30 \\
34 \\
13 \\
30 \\
50 \\
27 \\
18 \\
28 \\
28 \\
27 \\
58\end{array}$ & $\begin{array}{c}11,29 \\
9,10 \\
11 \\
2,9 \\
11,19 \\
11 \\
1,19 \\
11 \\
2 \\
2 \\
9,11 \\
11 \\
2,19 \\
2,11 \\
2,11 \\
2,9 \\
9,11 \\
2,11 \\
9,19 \\
2 \\
2,11\end{array}$ & $\begin{array}{r}5,7 \\
15,22 \\
15,40 \\
13,40 \\
5,15 \\
5,17 \\
8,15 \\
5 \\
15,40 \\
5,40 \\
15 \\
17,40 \\
7 \\
15,46 \\
16,40 \\
40,46 \\
13 \\
13,46 \\
17,35 \\
35,46 \\
40\end{array}$ & $\begin{array}{rl}> & 50 \\
> & 50 \\
> & 50 \\
40 & \\
35 \\
> & 30 \\
> & 30 \\
> & 30 \\
30 & 30 \\
& 30 \\
& 30 \\
& 25 \\
& 8 \cdot 0 \\
& 7 \cdot 0 \\
& 2 \cdot 1 \\
& 1.4 \\
& 1.0 \\
< & 1 \\
< & 1 \\
< & 1\end{array}$ & $\begin{array}{l}\text { Gen } \\
\text { Gen } \\
\text { Gen } \\
\text { Gen } \\
\text { Gen } \\
\text { Gen } \\
\text { Gen } \\
\text { Gen } \\
\text { Gen } \\
\text { Gen } \\
\text { Gen } \\
\text { Gen } \\
\text { Gen } \\
\text { Gen } \\
\text { Gen } \\
\text { Gen } \\
\text { Gen } \\
\text { Gen } \\
\text { Gen } \\
\text { Gen } \\
\text { Gen }\end{array}$ & $\begin{array}{l}- \\
- \\
- \\
- \\
- \\
- \\
- \\
- \\
- \\
- \\
- \\
\text { NR } \\
- \\
- \\
- \\
+ \\
+ \\
- \\
+ \\
-\end{array}$ \\
\hline $\begin{array}{l}\text { T } 2304 \\
\text { T } 864 \\
\text { T } 798 \\
\text { T } 2759 \\
\text { T } 794 \\
\text { T } 1187 \\
\text { MG } 859 \\
\text { T } 2170 \\
\text { T } 2269 \\
\text { T } 2287 \\
\text { MG } 1002 \\
\text { T } 2376 \\
\text { MG } 976\end{array}$ & $\begin{array}{l}\mathbf{F} \\
\mathbf{F} \\
\mathbf{F} \\
\mathbf{M} \\
\mathbf{F} \\
\mathbf{F} \\
\mathbf{M} \\
\mathbf{F} \\
\mathbf{F} \\
\mathbf{F} \\
\mathbf{F} \\
\mathbf{F} \\
\mathbf{F}\end{array}$ & $\begin{array}{l}58 \\
30 \\
25 \\
47 \\
35 \\
56 \\
36 \\
35 \\
35 \\
21 \\
27 \\
29 \\
24\end{array}$ & $\begin{array}{l}9,10 \\
9,11 \\
9 \\
2 \\
2 \\
2 \\
2,11 \\
2,9 \\
9,11 \\
11 \\
3,11 \\
9,11 \\
2,9\end{array}$ & $\begin{array}{l}15,40 \\
22 \\
40 \\
5,16 \\
46 \\
40,46 \\
46 \\
15 \\
15,16 \\
5 \\
16 \\
22,46 \\
5,40\end{array}$ & $\begin{aligned}> & 30 \\
& 6.5 \\
& 1 \cdot 5 \\
& 1 \cdot 2 \\
< & 1 \\
< & 1 \\
< & 1 \\
< & 1 \\
< & 1 \\
< & 1 \\
< & 1 \\
< & 1 \\
< & 1\end{aligned}$ & $\begin{array}{l}\text { Ocular } \\
\text { Ocular } \\
\text { Ocular } \\
\text { Ocular } \\
\text { Ocular } \\
\text { Ocular } \\
\text { Ocular } \\
\text { Ocular } \\
\text { Ocular } \\
\text { Ocular } \\
\text { Ocular } \\
\text { Ocular } \\
\text { Ocular }\end{array}$ & $\begin{array}{l}+ \\
\overline{+} \\
+ \\
+ \\
+ \\
+ \\
+ \\
+ \\
+ \\
+ \\
+ \\
-\end{array}$ \\
\hline $\begin{array}{l}\text { T } 2270 \\
\text { T } 799 \\
\text { T } 964\end{array}$ & $\begin{array}{l}\mathbf{F} \\
\mathbf{M} \\
\mathbf{F}\end{array}$ & $\begin{array}{l}35 \\
66 \\
58\end{array}$ & $\begin{array}{l}2,19 \\
2,10 \\
2\end{array}$ & $\begin{array}{c}15,40 \\
5 \\
15,40\end{array}$ & $\begin{array}{r}2.6 \\
22 \\
<1\end{array}$ & $\begin{array}{l}\text { NR } \\
\text { NR } \\
\text { NR }\end{array}$ & $\begin{array}{l}\overline{-} \\
\text { NR } \\
\text { NR }\end{array}$ \\
\hline
\end{tabular}

* gen $=$ generalised myasthenia gravis.

$\mathrm{NR}=$ Not recorded. 
Table 2 Prevalence of selected HLA antigens in adult myasthenics with and without acetylcholine receptor antibody

\begin{tabular}{|c|c|c|c|c|c|c|}
\hline$H L A$ antigen & $\begin{array}{l}A C h R<1 \\
o b s \\
n=13\end{array}$ & $\%$ & $\begin{array}{l}A C h R \geqslant 1 \\
\text { obs } \\
n=24\end{array}$ & $\%$ & $\begin{array}{l}\text { Controls } \\
o b s \\
n=110\end{array}$ & $\%$ \\
\hline $\begin{array}{l}\text { B5 } \\
\text { B15 } \\
\text { Bw46 }\end{array}$ & $\begin{array}{l}2 \\
3 \\
5\end{array}$ & $\begin{array}{l}15 \cdot 4 \\
23 \cdot 1 \\
38.5\end{array}$ & $\begin{array}{l}7 \\
9 \\
3\end{array}$ & $\begin{array}{l}29 \cdot 2 \\
37 \cdot 5 \\
12 \cdot 5\end{array}$ & $\begin{array}{l}10 \\
15 \\
29\end{array}$ & $\begin{array}{r}9 \cdot 1 \\
13.6 \\
26.4\end{array}$ \\
\hline
\end{tabular}

myasthenia gravis present in three of the adult patients.

HLA BW46 which was previously shown to be associated with juvenile onset myasthenia gravis ${ }^{7}$ showed no obvious difference in prevalence in adult patients compared with controls $(21.6 \%$ in patients, $26.4 \%$ in controls). There was an increased prevalence of both HLA B5 and HLA B15 in adult patients compared with controls but the differences were not statistically significant after adjustment for the number of antigens studied (HLA B5: $24.3 \%$ in patients, $9.1 \%$ in controls, $0.025<\mathrm{p}<0.05$ before adjustment. HLA B15: $32.4 \%$ in patients, $13.6 \%$ in controls, $0.01<\mathrm{p}<0.025$ before adjustment).

Table 1 shows that 18 of the 21 adult patients with generalised disease had AChR antibody compared with 4 of the 13 with ocular disease. This difference was statistically highly significant $\left(\chi_{1}^{2}=8 \cdot 34\right.$; $0.0025<p<0.005)$. The table also shows that 10 of the 13 adult patients with ocular myasthenia gravis had a history of Graves' disease compared with only three of 20 with generalised disease. This association was also statistically highly significant $\chi_{1}^{2}=10 \cdot 19$; $0.001<\mathrm{p}<0.0025)$ and strongly supports the association between ocular myasthenia gravis and thyrotoxic Graves' disease found in other ethnic groups. ${ }^{11}$

As expected, AChR antibody titres were generally much higher in the patients with generalised disease than in those with ocular disease. However, one patient with ocular disease (T2304) had an unusually high antibody titre but no evidence for disease involvement beyond the extra-ocular muscles.

In view of our previous suggestion ${ }^{7}$ that the presence of AChR antibody is related in some way to the host HLA phenotype, the frequencies of the HLA antigens of particular interest in adult patients with and without $\mathrm{AChR}$ antibody were compared in table 2. The frequencies of HLA B5 and HLA B15 were increased in patients with $\mathrm{AChR}$ antibody but not at a statistically significant level after adjustment for the number of antigens studied. There was an apparent increase in the prevalence of HLA BW46 in patients without AChR antibody and a decreased prevalence in patients with $\mathrm{AChR}$ antibody, which, although not statistically significant may have implications in view of the findings in the juvenile patients.

Of the 23 juvenile ocular myasthenics, seven had AChR antibody but the highest titre encountered was only 3.3 units. Twelve of the 16 patients without
AChR antibody and three of the seven patients with AChR antibody had HLA BW46. Three of the $23 \frac{\overline{0}}{\mathrm{~d}}$. juvenile patients (13\%) had HLA B15 and two $(8.7 \%)$ 줄 had HLA B5; these frequencies were not significantly different from those of the controls and suggest that HLA B5 and HLA B15 are unrelated to juvenile ocu-O lar myasthenia gravis.

\section{Discussion}

There are few published papers on the distribution of ${ }^{\infty}$ HLA antigens in Chinese myasthenics. Chee et al ${ }^{12} \stackrel{0}{\circ}$ reported an increased prevalence of HLA A26 in $30 \overrightarrow{\vec{\omega}}$ patients in Taiwan, and Lee et $a l^{13}$ reported an $\stackrel{\omega}{\sigma}$ increased prevalence of HLA DR4 in Shanghai. The 8th International Histocompatibility Workshop 5 included 17 Chinese myasthenic patients and 28 con- $\overrightarrow{0}$ trols but no firm conclusions could be drawn in view $\omega$ of the small numbers studied. Previously we ha $\overline{\mid c}$ reported a significantly increased prevalence of HL $\vec{A}$ BW46 in Chinese patients with juvenile ons git myasthenia gravis in Hong Kong. ${ }^{7}$ This antigen coul not be assigned in other previous studies of Chinesse myasthenics, 51213 and so the present study provide्d an opportunity to investigate the distribution of $\mathrm{HLA}$ BW46 in adult onset myasthenia gravis in Chinese $\overline{-}$

There was no increase in the prevalence of HLA. BW46 when the adult patients were studied as a whole. However, when the adult patients were separated on the basis of presence or absence of AChR antibodies there was an increased prevalence of HLA BW46 in patients without $A C h R$ antibody and $a \stackrel{2}{\triangle}$ decreased prevalence in those with $\mathrm{AChR}$ antibody. $\overrightarrow{\vec{F}}$ These observations were not statistically significant $\frac{0}{3}$ after adjustment for the number of antigens studied. $\frac{3}{2}$ However, the lack of statistical significance does not necessarily exclude the biological significance of the observations in view of the findings in the juvenile $\overline{\vec{J}}$ patients. Over $65 \%$ of the juvenile ocular patients had HLA BW46 and only one third had AChR antibody. The antibody titres in the juvenile patients were noticeably lower than those encountered in the adult $\frac{0}{3}$ patients. Thus, the findings suggest that, both in adults and children, ocular myasthenia gravis and its accompanying absence or low titres of $A C h R$ anti- $\frac{D}{2}$ body results from a pathological mechanism for which susceptibility is conferred by HLA BW46. This $\tilde{\sigma}$ antigen is also known to be associated with thyrotoxic Graves' disease in Chinese, ${ }^{14}$ and, as confirmed in this $\mathrm{N}$ 
study, Graves' disease is strongly associated with ocular myasthenia gravis of adult onset. Thus, the possibility cannot be excluded that ocular Graves' disease may accentuate ocular myasthenia gravis and bring the latter disorder more readily to notice. Whether or not the reverse is true and a significant number of patients with juvenile onset ocular myasthenia gravis will ultimately develop Graves' disease remains to be seen. Extended follow-up of the juvenile ocular myasthenics over many years will be necessary to resolve this issue.

Another finding of interest although not statistically significant was the slightly increased prevalence of HLA B5 and HLA B15. An increased prevalence of HLA B5 is also apparent in previous studies of Chinese and Japanese myasthenics although not always at a statistically significant level and not always commented upon. ${ }^{5121516}$ This finding may be related to the apparent association of HLA B5 with late onset Graves' disease in Chinese ${ }^{14}$ although the explanation for the relationship remains to be determined.

We are grateful to Miss Angela Ho and Mr Edward Choi for expert technical assistance and to Miss Yvette Chow for preparing the manuscript.

This work was funded in part by grants from the University of Hong Kong Research Grants Committee and the Faculty of Medicine, University of Hong Kong.

\section{References}

${ }^{1}$ Seybold ME. Myasthenia gravis. A clinical and basic science review. J Am Med Assoc 1983;250:2516-21.

${ }^{2}$ Lindstrom JM, Seybold ME, Lennon VA, et al. Antibody to acetylcholine receptor in myasthenia gravis: Prevalence, clinical correlates, and diagnostic value. Neurology (Minneap) 1976;26:1054-9.

${ }^{3}$ Drachman DB. Myasthenia gravis. New Engl J Med 1978;298:136-42.

${ }^{4}$ Garlepp MJ, Dawkins RL, Christiansen FT, et al. Auto- immunity in ocular and generalised myasthenia gravis. J Neuroimmunol 1981;1:325-32.

${ }^{5}$ Dawkins R. Myasthenia Gravis. In: Terasaki PI, ed. Histocompatibility Testing 1980. Los Angeles: UCLA Tissue Typing Laboratory, 1980:662-7.

${ }^{6}$ Compston DAS, Vincent A, Newsom-Davis J, Batchelor JR. Clinical, pathological, HLA antigen and immunological evidence for disease heterogeneity in myasthenia gravis. Brain 1980;103:579-601.

${ }^{7}$ Hawkins BR, Chan-Lui WY, Choi EKK, Ho AY. Strong association of HLA BW46 with juvenile onset myasthenia gravis in Hong Kong Chinese. J Neurol Neurosurg Psychiatry 1984;47:555-7.

${ }^{8}$ MacKinnon PCB. Introduction to Endocrinology. In: Weatherall DJ, Ledingham JGG, Warrell DA, eds. Oxford Textbook of Medicine. Oxford University Press, $1983 ; 10.3-10.96$.

${ }^{9}$ Hawkins BR, Ho AY, Choi EKK, Osmund IF. HLA antigens, glyoxalase $I$, and esterase D in Hong Kong Chinese. Hum Genet 1984;66:371.

${ }^{10}$ Garlepp MJ, Kay PH, Dawkins RL. The diagnostic significance of auto-antibodies to the acetylcholine receptor. J Neuroimmunol 1982;3:337-50.

${ }^{11}$ Dawkins RL, Christiansen FT, Garlepp MJ. Autoantibodies and HLA antigens in ocular, generalised and penicillamine-induced myasthenia gravis. Ann NY Acad Sci 1981;377:372-84.

${ }^{12}$ Chee CY, Chen RC, Hung TP, et al. Immunological studies on Chinese myasthenia gravis patients. J Formosan Med Assoc 1978;77:621-8.

${ }^{13}$ Lee TD, Zhao TM, Bu KJ, et al. Association of HLADR4 with myasthenia gravis in the Chinese. Tissue Antigens 1984;23:127-9.

${ }^{14}$ Hawkins BR, Ma JTC, Lam KSL, Wang CCL, Yeung RTT. Association of HLA antigens with thyrotoxic Graves' disease and periodic paralysis in Hong Kong Chinese. Clin Endocrinol (in press).

${ }^{15}$ Yoshida T, Tsuchiya M, Ono A, et al. HLA antigens and myasthenia gravis in Japan. J Neurol Sci 1977; 32:195-201.

${ }^{16}$ Garlepp MJ, Christiansen FT, Chiewsilp P, Dawkins RL. Myasthenia Gravis. In: Simons MJ, Tait BD, eds. Proceedings of the Second Asia and Oceania Histocompatibility Workshop Conference. Melbourne: Immunopublishing, 1983;343-7. 